\title{
CLINICAL NURSING CARE TO COMFORT WOMEN WITH ACUTE MYOCARDIAL INFARCTION ${ }^{1}$
}

\author{
Keila Maria de Azevedo Ponte², Lúcia de Fátima da Silva33, Antonia Eliana de Araújo Aragão \\ Cavalcante Guedes ${ }^{5}$, Ivete Palmira Sanson Zagonel ${ }^{6}$
}

${ }^{1}$ Article based on the dissertation - Tecnologias do cuidado clínico de enfermagem para o conforto de mulheres com Infarto Agudo
do Miocárdio, which was presented to Health and Clinical Nursing Care Graduate Program from State University of Ceará
(UECE) in 2011.
${ }^{2}$ Doctoral student at PPCCLIS/UECE. Holder of a grant by the Brazilian Federal Agency for Support and Evaluation of
Graduate Education Ceará, Brazil. Email: keilinhaponte@hotmail.com
${ }^{3}$ Ph.D. in Nursing. Professor in the Graduate and PPCCLIS/UECE courses. RN, Dr. Carlos Alberto Studart Gomes Hospital,
Messejana, Ceará, Brazil. Email: luthy2008@hotmail.com
${ }^{4}$ Ph.D. in Nursing. Nursing Undergraduate Course Coordinator at the Higher Institute of Applied Theology. Ceará, Brazil.
Email: antoniaeliana@superig.com.br
${ }^{5}$ Ph.D. in Nursing. Professor in the Graduate and PPCCLIS/UECE courses. Ceará state, Brazil. E-mail address: vilani.guedes@
globo.com
${ }_{6}$ Ph.D. in Nursing. Professor in the Graduate Program in Biotechnology applied to the Health of Children and Adolescents
and in the Nursing Undergraduate Course from Pequeno Príncipe School. Paraná, Brazil. Email: ivetesanzag@yahoo.com.br

ABSTRACT: The objective of this article was to describe the contribution of clinical nursing care to the environmental comfort of women with Acute Myocardial Infarction, based on the Comfort Theory and mediated by the research-care approach. Data collection took place from April to June 2011 with nine women admitted with an infarction to the Heart Hospital of Sobral, Ceará, Brazil. Four meetings were held; the first being four starting at the admission to the hospital. The participants were informed about the study objectives and the proposed method, and following care was provided based both on method and theory. Data collection was performed using individual semi-structured interviews, field diary, participant observation and thematic category content analysis. The clinical care implemented in the environmental context aimed at promoting adaptation to the coronary care unit and also providing an enabling environment for comfort and relaxed atmosphere. Clinical care targeted at promoting environmental comfort contributes to the wellbeing of women with infarction.

DESCRIPTORS: Nursing. Nursing care. Myocardial infarction. Women's health.

\section{CUIDADO CLÍNICO DE ENFERMAGEM PARA CONFORTO DE MULHERES COM INFARTO AGUDO DO MIOCÁRDIO}

RESUMO: Objetivou-se descrever a contribuição do cuidado clínico de enfermagem para o conforto ambiental de mulheres com Infarto Agudo do Miocárdio, com base na Teoria do Conforto e mediado pela pesquisa-cuidado. A coleta transcorreu de abril a junho de 2011 com nove mulheres admitidas por infarto no Hospital do Coração em Sobral, Ceará, Brasil. Foram quatro encontros com início na admissão hospitalar. Esclareciam-se os objetivos da pesquisa e a proposta do método, e logo ocorria o cuidado com base no método e na teoria. Na coleta das informações usaram-se entrevista individual, formulário, diário de campo, observação participante; na análise, categorização de conteúdo. Os cuidados clínicos no contexto ambiental buscaram promover adaptação à unidade coronariana, proporcionar ambiente propício para conforto e favorecer ambiente descontraído. Cuidados clínicos para implementar conforto ambiental contribuem para o bem-estar de mulheres com infarto.

DESCRITORES: Enfermagem. Cuidados de enfermagem. Infarto do miocárdio. Saúde da mulher.

\section{CUIDADO CLÍNICO DE ENFERMERÍA PARA EL CONFORT DE MUJERES CON INFARTO AGUDO DE MIOCARDIO}

\begin{abstract}
RESUMEN: El objetivo fue describir la contribución de la atención clínica de enfermería para el confort ambiental de mujeres con infarto agudo de miocardio, mediada por la investigación-cuidado basada de la Teoría del Confort. La recolección se llevó a cabo entre abril y junio del 2011 con nueve mujeres con infarto en el Hospital del Corazón en Sobral, Ceará, Brasil. Hubo cuatro reuniones a partir de la admisión. Se les informó de los objetivos y el método y el cuidado ocurrió basado en el método y la teoría. Para la recolección de las informaciones, se utilizaron la entrevista semiestructurada, diarios de campo, observación participante y análisis temático categorial de contenido. Los cuidados clínicos buscaron promover la adaptación a la unidad de cuidados coronarios, proporcionar un entorno adecuado para promover la comodidad y el ambiente relajado. La atención clínica para promover el confort ambiental contribuye al bienestar de las mujeres con infarto.
\end{abstract}

DESCRIPTORES: Enfermería. Atención de enfermería. Infarto del miocardio. Salud de la mujer. 


\section{INTRODUCTION}

This study approaches the clinical care aimed at providing environmental comfort to women with Acute Myocardial Infarction (AMI). Thus, in this study, clinical nursing care is addressed as the interventions performed by a researcher-caregiver to promote care aimed at providing environmental comfort based on the needs made evident during the study and also based on the Comfort Theory. ${ }^{1}$

When admitted to a Coronary Care Unit (CCU), people with AMI suffer sudden changes to their everyday life, because of the distress and emotional suffering caused by their experience of the unknown and loneliness, mainly because the hospitalization was sudden and unexpected. ${ }^{2}$

Clinical nursing care aimed at promoting the best possible comfort to people in these circumstances is essential, as they are exposed to several technical procedures and remain separated from their family context, away from their beloved relatives and have to interact with unfamiliar professionals. This situation may lead the patient to feeling uncomfortable within the hospital environment.

Two important aspects that should be taken into consideration are the family involvement in the patient's positive responses to treatment and promoting patients comfort, which is related to embracement, social and spiritual support, and communication. For this purpose, hospital managers should be informed about which elements of the hospital physical environment are related to the family convenience and the regular technical and scientific training of the healthcare staff. Furthermore, the essential state-of-the-art technologies aimed at patient comfort should be made available. ${ }^{3}$

Another essential aspect refers to choosing the most appropriate technology to be employed in nursing practice to provide patient comfort, as it has been observed that, in the intensive care environment, hard technologies are highly valued because such equipment is already available. Nevertheless, it should be highlighted that the soft and hard technologies ${ }^{4}$ are also available in this environment.

Soft technologies are indispensible for nursing practices within the hospital environment and they are employed from patient admission to discharge, focusing particularly on dialogue, touch, helping relationship, demonstrating concern, expressing affection and knowing how to listen. ${ }^{4}$

Overall, such attitudes are significant in interpersonal relations and this is why they should be enhanced in the care provided by nurses to hospitalized people. Actions like these, considered as soft technologies, may improve the patient's clinical status because they make the environment becomes pleasant and comfortable, which in this article is addressed according to the Kolcaba Comfort Theory. ${ }^{1}$ This Theory describes the environmental comfort focusing particularly on external conditions and influences including colors, lightning, sounds, noises, odor, temperature, natural and artificial elements, and the nurse should focus on the interaction between the patient and the surrounding environment. ${ }^{1}$ In addition, aiming at providing environmental comfort, the professional should be affectionate, warm, attentive, loving and provide the patient's growth, relief, security, protection, and wellbeing. ${ }^{5}$

Florence Nightingale, the first nursing theorist, had already described environmental comfort as a goal for nursing care. She was also concerned with a healthy environment, nourishment, sleep and rest, interaction with family and other people, personal hygiene and leisure activities as methods to be employed by a caregiver in order to promote patient wellbeing. ${ }^{6}$

According to this perspective, comfort was and still is studied by researchers, such as Florence Nightingale, ${ }^{6}$ Jean Watson, ${ }^{7}$ Fernanda Carneiro Mussi, ${ }^{3}$ Eloita Neves Arruda and Ana Maria Pereira Nunes ${ }^{5}$ and Katherine Kolcaba. ${ }^{1}$ But it was Katherine Kolcaba who explored this subject further, aiming at performing an extensive review of the literature in order to better define this term. Such concept means an immediate and holistic experience, strengthened by satisfying the needs for relief, desire and transcendence within physical, psycho-spiritual, socio-cultural and environmental contexts. ${ }^{1}$

In this article, comfort is described within the environmental context of females, provided that AMI is the leading cause of death in this group and there is growing importance for studies related to cardiovascular diseases in women. ${ }^{8}$

The main objective of this article was to describe the contribution of clinical nursing care in providing comfort to women with acute myocardial infarction based on the Comfort Theory and mediated by the research-care approach. 


\section{METHODS}

This qualitative study is characterized as research-care, i.e., it is an approach integrating research and care as essential elements for nurses' performance. Qualitative studies and the researchcare method are appropriate for investigations involving nurses, as their profession aims at human beings. ${ }^{9-10}$ Thus, it is relevant that methodologies be developed according to these characteristics so that reciprocity between professionals and patients can be maintained, with outcomes supporting the practice.

Comfort Theory was the chosen theoretical framework, which allows for understanding comfort as a result of nursing care. The theory's propositions are divided into three phases: 1 ) The nurse assesses the patient aiming at identifying comfort needs based on four contexts: physical, psycho-spiritual, socio-cultural, environmental and, simultaneously, implements interventions while considering the comfort provided by each action accomplished; 2) Activities related to promoting comfort are further enhanced and the patient is prepared to develop behaviors targeted to wellbeing by identifying comfort-promoting activities; and 3) Corresponds to the institutional integrity, when both the institution and the care team are ethically prepared to attempt at improving the quality of their services. This includes patient satisfaction, reducing costs, morbidity and hospital readmissions, as well as improved policies and health practices. ${ }^{1}$

This study involves only the first and second phases proposed in the theory because the third phase, of an institutional nature, transcends nursing care.

The following five steps should be fulfilled to enable a research-care approach: 1) Approaching the object of study; 2) Meeting with the researchedcared individual; 3) Establishing connections between research, theory and caregiving practices; 4) Distancing the researcher-caregiver from the researched-cared individual; and 5) Data analysis. ${ }^{9}$

\section{Approaching the object of study}

This approach occurred due to family reasons, because of the experience of the lead researcher as a clinical nurse and from working in the line of research addressing this subject in the Health and Clinical Nursing Care Graduate Program. The organization of the literature review was also important in assisting the delineation of the object of study, in order to analyze the exist- ing knowledge, provide new approaches to this subject, offer security to the researcher, allow for designing a research follow-up model, and finding knowledge gaps in the field of study.

Thus, the interrelation between the methodological strategy and the object of study was considered. According to the founders of this investigation method, there is a possible discussion between the researcher-caregiver and the researched-cared individual regarding the "alternative actions targeted to reduce discomfort or improve comfort levels". 9:75

\section{Meeting with the researched-cared individual}

The meeting took place at the CCU and Emergency Care Unit of the Heart Hospital in Sobral, Ceará, Brazil. This is an important hospital for the care to people with heart disorders in Northern Ceará. This hospital has one of the most important programs for the treatment of AMI in Brazil with excellent indicators for low mortality and reduced number of hospital re-infarction. Furthermore, this hospital stands out by its involvement in international cardiovascular multicenter trials.

The researched-cared individuals were women, 18 years of age or older, admitted to the hospital during the data collection period (April to June of 2011), who had a history of medical diagnosis of a first hospitalization related with AMI. Within this period, 66 individuals were admitted to the hospital with an AMI diagnosis, 18 of which were females; however, nine were excluded because four died at admission, four were admitted between midnight and five a.m., and one had been hospitalized before. Therefore, nine women were researched-cared in this study.

The first meeting lasted nearly six hours and was complemented by three other meetings in the following days, each of them lasting nearly four hours. In order to ensure the presence of the researcher-caregiver during the admission of the researched-cared woman, a mobile phone was handed to nurses at the CCU so they could immediately call the researcher-caregiver whenever a woman with AMI was admitted to the hospital. The patients were informed about the research objectives and method proposal, and nurses then proceeded with care based on method and theory.

This study was approved by The State University of Ceará Research Ethics Committee (protocol 10727050-3) on February 17, 2011. All participants signed the Terms of Free and In- 
formed Consent, and all ethical principles related to human research have been observed.

\section{Establishing connections between research, theory and caregiving practices}

A connection was established between research (data collection), theoretical framework (Comfort Theory) $)^{1}$ and caregiving practices. In each case, the care priorities were established for each specific phase. Therefore, clinical nursing care was implemented through interventions/actions aimed at meeting the needs of environmental comfort expressed through verbal and non-verbal communication from the cared individual, as well as through prior experience and knowledge of the researcher-caregiver. ${ }^{9}$

Semi-structured interviews were conducted with the participants, who answered the following guiding question: what can I do to provide you comfort at this moment? To achieve the study objective, the participants' environmental comfort needs were extracted from their answers to the aforementioned question. The question was applied within the first six hours of interaction and in the following meetings, at the time perceived as the best moment for questioning. There was no interference by the researcher-caregiver in the participants' statements, which were recorded using a digital recorder. The strategies used for data collection were interviews, completion of a form specifically developed for data collection in this study, containing personal information and data regarding the disease, participant observation regarding the comfort care provided and field diary records.

\section{Distancing between the researcher-caregiver and the researched-cared individual}

This phase was prepared from the very first contact with the researched-cared individual, so they would not build expectations that the care they were receiving for study purposes would be continued. However, the participants were assured they would continue receiving care from the unit's nursing team after the meetings ended. After the final meeting, the researched-cared individuals exposed feelings they had kept concealed until then. They also showed satisfaction towards having participated in the study, and exchanged compliments with expressions of care and affection. However, it was also clear they felt sad in face of the ultimate separation.

\section{Data analysis}

In this phase, the data were arranged by means of content analysis and analyzed based on the theoretical framework. In order to observe human research ethics, the researched-cared women were identified using the term "researched-cared" or " $R C^{\prime}$ ", followed by the entry number of each interviewee. All data collected using the collection instruments were fully transcribed. A thorough reading of the material was performed, followed by pre-analysis, until comprising the corpus of analysis, corresponding to the moments when the researched-cared individuals reported they felt comfort within the environmental context. After examining the material, excerpts were removed from the sentences, revealing emerging and significant categories based on the Comfort Theory and on the relevant literature on this issue.

\section{RESULTS}

The clinical nursing care performed for implementing the environmental comfort within this context was targeted to promote adaptation of the researched-cared women to the Coronary Care Unit and provide a comfort-promoting environment and a relaxed atmosphere.

\section{Promoting the adaptation of the researched- cared women to the Coronary Care Unit}

The women's initial moments of hospitalization at the CCU were marked by the attempt to adapt them to that sector. They were in a completely new social environment, entrenched with stigmas. For this purpose, the researcher-caregiver expressed her interest in those women and in their disease processes. She held their hands, called them by the name, showed them around the new environment, and provided them with relevant information, while performing the necessary care and conducting the investigation.

Nevertheless, this study pointed out that identifying care strategies' to address environmental comfort becomes challenging when other hospitalized people are involved. Therefore, one should be careful to satisfy their needs without interfering in the comfort of others.

At the first contact with the researched-cared women, which occurred almost entirely at the emergency care unit, there were no complaints related to the environment. Perhaps this fact occurred because they were focused on clinical 
manifestations, especially precordialgia. However, the researcher-caregiver was attentive to the discomfort caused by excessive luminosity and the noise from conversations involving other patients, relatives and hospital employees.

Consequently, the conduct of choice was the attempt to speed up the transfer of the researchedcared women to the CCU and, in case this was impossible, provide the best possible privacy until they were called to the unit. At the CCU, as the researcher-caregiver developed her interaction with the researched-cared women developed, she provided information regarding the environment while identifying each woman's needs, aiming at improving the environmental comfort.

At the CCU, the researched-cared women remained alert regarding the environmental context; they observed the movement of healthcare professionals, the environment around them, the condition of other patients, often understanding what happened around them. During one of the meetings, one of the patients died next to a researchedcared woman 4 . She remained attentive to this fact and made questions concerning that issue. The researcher omitted this information to maintain the environmental and psycho-spiritual comfort, because witnessing the death of a patient with a similar clinical situation is not always perceived as normal. Therefore, health professionals should preserve patients under their care from unpleasant information of no relevance to them, especially if professionals are unaware regarding the patient's preparation to receive such information.

\section{Providing an enabling environment for comfort}

Since the first meeting, the aspects related to the environmental context became evident. For example, preferences concerning lightning and temperature were described as follows: I feel bad because of the light, I prefer to wear my glasses [...] (RC2); I don't like the light on my face (RC6); I am cold (RC7); I did not sleep very well last night, the lights were on and I didn't want to ask to shut them down, I was embarrassed [...] (RC1).

Because of previous eye problems, RC2 had an aversion to light. Therefore, she often wore sunglasses. Due to this fact, the researcher-caregiver controlled the lightning in the environment whenever this was possible, especially the lights next to her. Strategies related to clinical nursing care for environmental comfort were promoted, including controlling the environmental temperature, offering blankets, providing heating massages and skin to skin contact, which included embracing.

The environment was observed while interacting with the researched-cared women in order to identify factors that could cause discomfort. The following factors were observed: excess luminosity; alarms from infusion pumps, monitors and mechanical ventilators; and unpleasant odors (presence of a patient hospitalized in critical condition without sphincters and septic control). Professionals are required to proceed with their actions carefully. On a certain occasion, when installing an oxygen therapy pressure-reducing valve, a nursing assistant made a noise that bothered a patient who was resting.

A positive aspect related to the hospital environment, which became evident in this study, was described by RC6 and her husband while talking to a researcher-caregiver. They were surprised by the beauty of the hospital, and this demonstrates that by providing care it is also important considering environmental aspects and visual comfort.

At the third meeting, there still were reports concerning lightning and temperature. However, some women stated: the cold temperature here is really nice and it helps to sleep well (RC1).

Other women prefer milder temperature. While some women preferred having the lights on while resting, others felt extremely bothered especially when lights were directly upon them. Therefore, it is important to identify the needs of each person aiming at providing environmental comfort.

Regarding the noise in the unit, it was observed that noise was so loud that it interfered in the decoding process in some of the statements recorded during the interviews. Thus, environmental silence campaigns should be promoted, because the intensive care environment must be appropriate for resting.

\section{Promote a relaxed atmosphere}

Although this is an intensive care environment, this place should be harmonious and also promote leisure and relaxation, whenever this is possible. Therefore, similar experiences have been witnessed in this study. For example, by removing an intra-arterial device from RC5, she offered her son in marriage to either the researcher-caregiver or nursing who was performing such procedure. That was a relaxing moment between that patient and the nurses. 
In this study, it was observed that the researched-cared women found some distraction and relaxation from observing the movement of the healthcare staff: I lie here, praying, watching the movement of the girls, all of them are delicate, cheerful, and no one is ever in a bad mood [...] (RC6).

While at the care unit, the women talked to each other thus, establishing a social interaction that allowed them to talk about several issues, including some humorous subjects.

Another strategy used to provide comfort was to offer books to patients who were able to read. Encouraged by the researcher-caregiver, RC2's daughter brought her a book and she reported it promoted a feeling of comfort. Another useful technology is music therapy either individual or, when possible, environmental. In one of the meetings, RC2 stated: at night, they put a song and I could hear from here, Paula Fernandes [...], I liked her music [...]. They played it softly (RC2).

Another method used for the women's relaxation was the conversations that the professionals had with the patients, supporting them and listening to their needs, providing what they needed to feel comfortable. The researcher-caregiver would often ask what she could do to provide comfort, and the researched-cared women would reply: just stay here close to me (RC3).

Finally, conversations may also provide funny stories such as that reported by researchedcared woman 9, who talked about her husband who left the house to do some shopping around 25 years ago and never came back: I think he is still shopping. He's been shopping for quite some time! [Laughs] (RC9).

\section{DISCUSSION}

The word comfort comes from Latin confortare and, in English, this term means strengthening, ensuring, granting, consoling, relieving, assisting, helping and aiding. It may have different meanings for each person according to their personal experiences. It is a state of personal and environmental balance. ${ }^{11}$

From the perspective of AMI patients, comfort can be described in many ways, and does not depends exclusively on nursing care. In their view, comfort is related to material or financial conditions, enjoying personal interactions, experiencing psychological, physical and spiritual wellbeing, "functioning normally", i.e., hoping to recover one`s health, not falling ill and being able to perform the everyday activities. ${ }^{12}$
According to the Comfort Theory, nursing care within the environmental context is aimed at external conditions and influences, such as colors, lightning, sounds, scents and temperature. ${ }^{1}$

Evidence shows that nursing employs comfort care through multiple actions, verbal and nonverbal communication, care with the environment, respect towards patients, and pain relief, in addition to always keeping calm, which emphasizes the relevance of the relationship between the caregiver and the cared individual. ${ }^{13}$

The meanings assigned to no-comfort/discomfort for relatives or others accompanying the patient within the hospital environment include the lack of convenience, nuisance, unaddressed rights, stress, precarious conditions of the hospital structure and functioning, all of which are needs that can be met through care actions. ${ }^{14}$

The nurse should focused the environment as a whole, as it promotes healing and health. Thus, it is important make careful choices regarding colors, perform effective management of noise, lightning and temperature, and assure that patients can look outside their room, and see natural and artificial elements. Furthermore, the surrounding environment is a place with a high flow of people, and this should be taken into consideration regarding the ventilation, storage of equipment and any other devices associated with the patient. ${ }^{1,15}$

These factors must be considered when implementing clinical nursing care aiming at providing comfort within the environmental context. In the present study, the identified factors were related to managing equipment noises, reducing conversations in the room, and controlling excessive lightning, unpleasant odors, and the temperature. Such interventions provided comfort to the participants.

Another relevant aspect affecting the comfort of hospitalized patients is the constant whispering from conversations among healthcare professionals. It is worth remembering that in intensive care silence should be preserved as a method for reassuring patients. Furthermore, it is evident, particularly in this study, that in addition to the perception resulting from experience of the researcher-caregiver, patients remained attentive to what they heard. There is clearly no intention to suggest that people should remain completely silent in such a stressful environment; however, there is a need for special care when choosing which subjects are discussed. Personal conversations as well as any issues related to clinical status 
of patients should be avoided, with the purpose to comply with the ethical aspects involved in the process of care.

It is important to recall that the CCU is a distinct unit because its main characteristic is the higher incidence and prevalence of death as compared to other hospital sectors, in which concepts of life and death are intertwined and constitute an additional burden on patients with AMI. Thus, hazards may exist to meeting the basic human necessities of these patients. ${ }^{16}$

During the period of illness, it is observed that the usual comfort of AMI patients at the CCU is impaired. They suddenly see themselves requiring the help of others (caregivers) in order to perform everyday activities they were once capable of doing on their own, in order to avoid cardiac stress.

The premises of the Comfort Theory comply with the holistic theory, in which humans present global responses to complex stimuli and one's physical body is related to mind, spirit, emotion, environment and society. ${ }^{1}$

Another aspect found in the present study regarding the promotion of a comforting environment by provide a relaxing atmosphere is the appreciation of joy and keeping a good mood, avoiding to talk only about the disease and emphasizing interpersonal communication. Good mood and joy, which are represented by laughter, are capable of relieving stress within a context of pain and suffering. ${ }^{17}$

Reading is also one of the best instruments employed to promote leisure to hospitalized patients in intensive care units, because it is effortless and patients can do it in bed. Reading should be considered as a way of entertaining intensive care unit patients.

Along with reading, music therapy is also a soft technology that provides comfort and wellbeing to people within the hospital environment, especially because both have a positive effect on that place, and, thus, strengthen the relationship between healthcare professionals and patients. Therefore, it is important to highlight the importance of communication and interpersonal relations skills when providing care because they express attention, compassion and comfort to people facing a disease..$^{18-19}$

Thus, conducting this study, which involved the research-care approach and the Comfort Theory, allowed for integration and approxima- tion between researcher-caregiver and researchedcared women. Furthermore, this study also provided immediate comfort-triggering outcomes within the environmental context through the implementation of care based on the identified individual needs.

\section{CONCLUSION}

A positive analysis was made of the contributions of clinical nursing care targeted to promote comfort to women with AMI based on the Theory of Comfort and mediated by the research-care approach. The care provided aimed at making the adaptation to the CCU comfortable and to provide an enabling environment for comfort and a relaxed atmosphere. In order to promote comfort, the healthcare professional is required to establish attachment, dialogue and confidence while providing care, aiming at identifying individual comfort needs and implementing the respective comfort care.

It is important to highlight that conducting this study was especially motivating for the researcher because it has allowed promoting care based on the identification of the environmental comfort needs of each patient. Therefore, it became evident that the implementation of these actions made a difference in the care delivered to the participants. From this perspective, it is essential for nursing assistants, managers and faculty to consider the training process and professional clinical practices carefully to build awareness among nursing professionals, to meet the environmental comfort needs of patients under their responsibility.

A number of limitations became evident throughout this study. Among them, it can be mentioned the fact of some care practices have been limited by procedures and/or protocols determined at the hospitalization unit, and also the irregular presence of the researcher along with the researched-cared women. This latter fact suggests that there has been loss of contact between one meeting and another. Clearly, some situations within the study period required the implementation of comfort care provided by the researcher-caregiver.

Nevertheless, the women with AMI involved in this study were benefitted from having their environmental comfort needs satisfied. This was only made possible because they were active participants in the care and facilitators in this research 
as, during the meetings, they demonstrated their needs for comfort.

Further studies should be considered concerning comfort as an outcome for clinical nursing practices, especially those that involve the individuals to be cared as active participants. This would allow an immediate application of the outcomes in education and professional training. Therefore, it is suggested that new studies be conducted focusing on identifying and satisfying comfort needs in several situations of the continuum health-disease process in humans. As a healthcare professional, nurses are capable of identifying and providing wellbeing across different contexts of the healthdisease process in humans.

\section{REFERENCES}

1. Kolcaba K. Comfort theory and practice: a vision for holistic health care and research. New York (US): Springer Publishing Company; 2003.

2. Schneider DG, Manschein AMM, Ausen MAB, Martins JJ, Albuquerque GL. Acolhimento ao paciente e família na unidade coronariana. Texto Contexto Enferm. 2008 Jan-Mar; 7(1):81-9.

3. Freitas KS, Meneses IG, Mussi FC. Conforto na perspectiva de familiares de pessoas internadas em Unidades de Terapia Intensiva. Texto Contexto Enferm [online]. 2012 Out-Dez [acesso 2013 Ago 19]; 21(4). Disponível em: http://www.scielo. br/scielo.php?script=sci_arttext\&pid=S010407072012000400021\&lng=pt\&nrm $=$ iso

4. Silva DC, Alvim NAT, Figueiredo PA. Tecnologias leves em saúde e sua relação com o cuidado de enfermagem hospitalar. Esc Anna Nery [online]. 2008 Jun [acesso 2010 Nov 10]; 12(2). Disponível em: http://www.scielo.br/pdf/ean/v12n2/v12n2a14. pdf

5. Arruda EN, Nunes AMP. Conforto em enfermagem: uma análise teórico-conceitual. Texto Contexto Enferm. 1998 Mai-Ago; 7(2):93-110.

6. International Council of Nurses. Notas de enfermagem: um guia para cuidadores na atualidade. Rio de Janeiro (RJ): Elsevier; 2010.

7. Watson J. Enfermagem: ciência humana e cuidar uma teoria de enfermagem. Portugal (PT): Lusociência; 2002.

8. Melloni C, Berger JS, Wang TY, Gunes F, Stebbins A, Pieper KS, et al. Representation of women in Randomized Clinical Trials of cardiovascular disease prevention. Circ. Cardiovasc Qual Outcomes [online]. 2010 Ago [acesso 2010 Mai 20]. Disponível em: http://circoutcomes.ahajournals.org/content/ early/2010/02/16/CIRCOUTCOMES.110.868307. full.pdf
9. Neves EP, Zagonel IPS. Pesquisa-cuidado: uma abordagem metodológica que integra pesquisa, teoria e prática em enfermagem. Cogitare Enferm [online]. 2006 Jan-Abr [acesso 2010 Set 25]; 11(1). Disponível em: http://ojs.c3sl.ufpr.br/ojs2/index. $\mathrm{php} /$ cogitare/article/view/5980/4280

10. Lacerda MR, Giacomozzi CM, Przenyczka RA, Camargo TB. Pesquisa-ação, pesquisa convergenteassistencial e pesquisa cuidado no contexto da enfermagem: semelhanças e peculiaridades. Rev Eletr Enf [online]. 2008 [acesso 2011 Out 23]; 10(3). Disponível em: http://www.fen.ufg.br/revista/ v10/n3/v10n3a31.htm

11. Rosa LM, Mercês NNA, Santos VEP, Radünz V. As faces do conforto: visão de enfermeiras e pacientes com câncer. Rev Enferm UERJ. 2008 JulSet; 16(3):410-4.

12. Mussi FC, Friedlander MR, Arruda EN. Os significados da palavra conforto segundo a perspectiva do paciente com infarto agudo do miocárdio. Rev Latino-Am Enferm [online]. 1996 Dez [acesso 2010 Set 15]; 4(3). Disponível em: http:/ / www.scielo.br/scielo.php?script $=\mathrm{sci}_{-}$ arttext\&pid=S0104-11691996000300003

13. Silveira IP. Teoria do Conforto para promoção da saúde no cuidado de enfermagem à parturiente. [tese na internet]. Fortaleza (CE): Departamento de Enfermagem, Universidade Federal do Ceará; 2010 [acesso 2012 Ago 2]. Disponível em: http://www.repositorio.ufc.br:8080/ri/ bitstream/123456789/2100/1/2010_tese_ipsilveira. pdf

14. Koerich CL, Arruda EM. Conforto e desconforto na perspectiva de acompanhantes de crianças e adolescentes internados em um hospital infantil. Texto Contexto Enferm. 1998 Mai-Ago; 7(2):219-43.

15. Silva CRL, Carvalho V, Figueiredo NMA. Ambiente e tecnologia: uma reflexão acerca do cuidado de enfermagem e conforto no ambiente hospitalar. Rev Pesqui Cuid. Fundam [online]. 2010 Abr-Jun [acesso 2011 Out 08]; 2(2). Disponível em: http:/ / www.seer. unirio.br/index.php/cuidadofundamental/article/ viewFile/313/pdf_23

16. Oliveira MA, Albuquerque GA, Alencar AMPG. Satisfação do cliente portador de infarto agudo do miocárdio acerca dos cuidados de enfermagem. Rev Rene. 2009; 10(1):95-103

17. Araújo MMT, Silva MJP. A comunicação com o paciente em cuidados paliativos: valorizando a alegria e o otimismo. Rev Esc Enferm USP [online]. 2007 Dez [acesso 2011 Mai 07]; 41(4). Disponível em: http://www.scielo.br/scielo.php?script=sci_ arttext\&pid=S0080-62342007000400018

18. Bergold LB, Alvim NAT. Visita musical: estratégia terapêutica fundamentada na Teoria do Cuidado Transpessoal. Online Braz J Nur [online]. 2008 [acesso 2011 Ago 06]; 7(1). Disponível em: http:// 
www.objnursing.uff.br/index.php/nursing/ article/view/j.1676-4285.2008.1469/303

19. Araújo MMT, Silva MJP. Estratégias de comunicação utilizadas por profissionais de saúde na atenção à pacientes sob cuidados paliativos. Rev Esc Enferm USP [online]. 2012 Jun [acesso 2012 Ago 30]; 46(3). Disponível em: http://www.scielo. br / scielo.php?script $=$ sci_arttext\&pid $=$ S0080 62342012000300014\&lng=pt\&nrm=iso\&tlng=pt 